\title{
LEVELS OF ANALYSIS FROM THEORY TO PRACTICE - CASE STUDY: U.S. POLICY IN THE EAST SEA UNDER THE TRUMP ADMINISTRATION
}

\author{
Pham Minh Thu* \\ Diplomatic Academy of Viet Nam, Americas Department, Ministry of Foreign Affairs \\ 69 Chua Lang, Dong Da, Hanoi, Vietnam
}

Received 02 March 2020

Revised 15 May 2020; Accepted 27 May 2020

\begin{abstract}
Three levels of analysis (individuals, nation states and international system) which have been widely recognized in foreign policy are applicable in explaining whether the Trump Administration has actually had a policy in the East Sea. At individual level, President Trump first announced the U.S. "Free and Open Indo - Pacific Strategy" in November 2017, in which the East Sea is known as an important factor of security pillar to preserve vitality of free and open air and maritime space in the region. It was then echoed at national level by national strategies, including the National Security Strategy, National Defense Strategy and National Military Strategy. Also, members of the U.S. Cabinet and Congress have shown support for the Indo - Pacific Strategy in general and the U.S. policy in the East Sea in particular. In order to cope up with China's assertiveness in this waterway at systematic level, the Trump Administration has unceasingly projected considerable its power, including increasing military presence and regional maritime capacity building efforts as well as frequent freedom of navigations (FONOPS). In the context that territorial disputes remain complex and unforeseeable, it is valuable to have a thorough look at the Trump's East Sea policy for claimants in this water, including Viet Nam.
\end{abstract}

Keywords: Levels of analysis, Trump, policy, East Sea.

\section{Introduction}

Three levels of analysis (individuals, nation states and international system) have been long developed and widely recognized in foreign policy. Under the Trump Administration, these levels are applicable in explaining whether the Administration has set a policy in the East Sea. In the context that territorial disputes in this region remain complicating, it is worth seeking answer for this research question which will have strategic implications for claimants, including Viet Nam.

\footnotetext{
Tel.: 84-912610000
}

Email: phamminhthu251@gmail.com

\section{Levels of analysis}

It is disputable whether the U.S. Administrations, including the Trump Administration, have ever had an overall East Sea policy. If yes, how it has been formatted and implemented to achieve its national interests in this waterway. Hence, the article is tracking down the three levels of analysis to seek answers for these above-mentioned research questions.

In the book "Man, the State and the War" published in 1959, Kenneth Waltz first mentioned three analytical levels (which are also known as "images"), including individuals, nation states and international 
system. According to Kenneth Waltz, there are three "images" to explain conflicts and wars in international relations. While individual level points out human nature such as ambitions, selfishness and characteristics have impacts on foreign policy making, national state level helps explain that domestic politics are causes of wars. Otherwise, international level helps define forces which put constraint on individuals and states in policy making (Ikenberry, 2014) . Kenneth Waltz assumed that international level outperforms other levels.

These levels were then developed by David Singer (1961) in the article "The level of Analysis Problem in International Relations" in World Politics. Singer (1961: 77-92) regarded international level as "the most comprehensive of the levels available, encompassing the totality of interactions which take place within the system and its environment". However, Singer also pointed out its shortcomings. Particularly, this level "exaggerates the impact of the system upon the national actors and, conversely, discounts the impact of the actors on the system". Meanwhile, national level "permits significant differentiation among our actors in the international system". Additionally, Singer explained that nations include groups of individuals in a certain institution. Then, it is necessary to study individual role in the policy making.

Modern scholars have shown their interest in the three levels of analysis, namely Professor J.T. Rourkev and M.A. Boyer, Connecticut University (Rourke \& Boyer, 2010) or Christophe Barbier, Norwhich University (Academia) to explain policymaking and implementing process. Unlike other scholars, Christophe Barbier assumed that individual level plays a core role in the policy making.
Generally speaking, levels of analysis are popularly recognized in foreign policy even though there may be different views on which level overwhelm others. Remarkably, the three levels are not independent. Instead, they are interactive in the process of foreign policy making and implementing, depending on certain historic periods and specific matters.

\section{U.S. policy in the East Sea under the Trump Administration}

Levels of analysis and their interactions are basically explainable in the US politics in general and its policy making in particular. Through a profound study of the three analytical levels, an East Sea policy under the Trump Administration should be revealed.

First and foremost, at individual level, U.S. President leads the formation of foreign and domestic policies in the U.S. Administration as described in Article 2 of the U.S. Constitution. Then, is is unexceptional for President Trump who is well-known for his strong leadship. Under the Trump's Administration, "American First" approach does not stop him from attaching global strategic focus to the Indo-Pacific with the aim to maintaining the U.S.'s super power status. After taking office in January 2017, President Trump early eliminated "Rebalancing" and replaced it with a new "Free and Open Indo - Pacific Strategy". At APEC Summit in late November 2017 in Da Nang, President Trump directly emphasized that Indo - Pacific region would be "a place where sovereign and independent nations, with diverse cultures and many different dreams, can all prosper sideby-side, and thrive in freedom and in peace" (White House, 2017). Remarkably, one of the Free and Open Indo - Pacific Strategy's objectives is to preserve vitality of free and open air and maritime space in the region. The commencement speech by President Trump at 
the U.S. Naval Academy in 2018 highlighted the U.S. as a maritime nation. That is why the U.S., according to President Trump must always dominate that sea and oceans". Actually, the influence of sea power was first envisioned by the U.S. well-known naval historian, strategist and geopolitical theorist, Alfred Thayer Mahan. As stated by Mahan, control of seaborne can determine the winner and loser of wars. Since then, this ideology has been traditionally recognized by multiple U.S. Presidents. Nowadays, U.S. sea power, constituting several interrelated capabilities, including forward presence, deterrence, sea control, power projection, maritime security, humanitarian aid (CFR, 2019), bears not only military but also diplomatic significance for U.S. to maintain its superpower status.

At national state level, U.S. President is the leading, but not the sole, player in formatting and implementing the U.S. foreign policy. This process is largely joined by members of the Cabinet. Also, the U.S. Congress, together with other players, involves in formatting the U.S. foreign policy under "checks and balances" (Freegman, 1971: 35).

Though not a claimant in the East Sea, the U.S. Administration, including the Trump Administration, has long asserted its vital national interest in this waterway. U.S. Under Secretary of Defense for Acquisition and Sustainment Alan Shaffer believed that China's military build-up was threatening U.S. and allied interests in the Western Pacific and in the East Sea in particular (U.S. Department of State, 2020). Vice President Mike Pence emphasized that "Beijing's policies most harmful to America's interests and values, from China's debt diplomacy and military expansionism" (White House, 2019). In general, U.S. national interests in the East Sea can be felt in economic, military and strategic terms.
Economically, the United States' merchant shipping is less reliant on the East Sea, in comparison with China and Japan, with just over 14 percent (CSIS). However, as a super power of energy, the U.S. heavily depends on external supply of resources. Accounting for only 4.6 percent of the world's population, the U.S. consumes up to 25 percent of the world's oil. This fact, consequently, has led to "its strategic vulnerability" and constrained "its ability to pursue foreign policy and national security objectives" (CFR, 2006). Also, the oil shock in 2008 showed how energy security means to the U.S. giant economy indeed. While developing alternative resources of energy, including schist, oil and natural gas remain on the top of the list. In order to safeguard energy stability, the US is obliged to stretch out of its territory to compete with others in the fight for exploring foreign potential reserves, including the East Sea's reserves. China's ambiguous "nine dash line" claim in the East Sea comprises nearly $80 \%$ of the whole sea. At a joint conference in Manila in February 2019, U.S. Secretary of State Mike Pompeo pointed out that "China's island building and military activities in the East Sea threaten (Philippine) sovereignty, security and therefore economic livelihood, as well as that of the United States" (Cabato \& Mahtani, 2019). Moreover, the U.S. has interests in securing unimpeded lawful trade through the East Sea, as repeated by many high-level officials.

Militarily and strategically, the East Sea is an extremely important sea lane to the U.S.'s defense networks and security links. On the one hand, the U.S. needs to bring security assurance to its regional allies, namely the Philippines and Taiwan, both of which make territorial claims in the East Sea. On the other hand, against the backdrop of China's rapid military build-up, the US needs to deter 
China's desire from controlling the East Sea and protecting the rule-based order in the region. Every year, the U.S. conducts multiple bilateral and multilateral joint exercises, including the largest one in Asia, Cobra Gold. Then, any impediment to the free flow of both merchant and military shipping in the East Sea is a nuisance to the U.S. However, China's recent military build-up with an ultimate aim to replace the U.S. in the region has presented a credible threat to the U.S.'s national interests. According to James Fanell, a former Navy intelligence officer, "China will have about 550 warships by 2030 - nearly double the size of today's U.S. Navy" (Dorell, 2018). Since 2013, China has increasingly engaged in unprecedented and massive dredging and artificial island reclamations in the East Sea, expanding 3,200 acres of new land. More dangerously, those outposts have been significantly installed with long-range sensor arrays, port facilities, runways, and reinforced bunkers for fuel and weapons. The U.S. Department of Defense's 2019 annual report acknowledged that China has not conducted any new activities of militarization since its placement of air defense and antiship missiles in the Spratly islands in 2018. However, it is not, indeed, a positive signal to give the U.S. in particular and the region in general a big relief. Gen. Joseph Dunford, the Chairman of the U.S. Joint Chiefs of Staff in the conversation with the Brooking Institution in May 2019 insisted that if China's military build-up had peaked, it was because China had remarkably achieved its immediately military goals. Now, China is believed to have enough military capability "to monitor rivals" air and sea movements" and its artificial outposts can be utilized "as a base for coast guard and maritime militia operations against those countries' fishermen and hydrocarbon exploitation" (Stashwick,
2019). Consequently, it has posed threats to not only the U.S. navy's operations but also a rule-based order in the region which has been terribly destroyed by China's illegitimate unilateral expansionism.

Acknowledging national interests in the East Sea, the Trump Administration has shown its consensus in boosting proactive engagement in the Indo - Pacific in general and the East Sea in particular. The National Security Strategy (NSS) 2017, the National Military Strategy 2018 (NMS 2018) and the National Defense Strategy (NDS 2018) (White House, 2017), the most U.S. important national strategies, stated why the U.S. should maintain and increase its active engagement in the region. NSS 2017 realized that China's efforts "to build and militarize outposts in the East Sea" endangered "the free flow of trade", threatened "the sovereignty of other nations", and undermined "regional stability". Then, the NSS 2017 reaffirmed the U.S's commitments to freedom of the seas and the peaceful resolution of territorial and maritime disputes in accordance with international law". Meanwhile, the National Military Strategy 2018 (Joint Chief of Staff, 2018) (NMS 2018) pointed out that the reemergence of great power such as China and Russia has posed the most difficult challenges to the U.S. The National Defense Strategy (NDS 2018) highlighted that "China is leveraging military modernization, influence operations, and predatory economics to coerce neighboring countries to reorder the Indo-Pacific region to their advantage" (U.S. Department of Defense). Members of the U.S. Cabinet and other defense officials have also reaffirmed the U.S.'s rights of freedom of navigation. At the East Asia Summit in Singapore in November 2018, Vice President Mike Pence, while criticizing China's militarization and territorial expansion in the East Sea as 
"illegal and dangerous", reaffirmed that the U.S. "will continue to fly and sail wherever international law allows and our national interests demand. Harassment will not deter us; it only strengthens our resolve" (White House, 2019). In November 2019, Secretary of Defense Mark Esper stated that the U.S. had conducted "more freedom of navigation operations in the past year or so than we have in the past 20-plus year" (CFR, 2019). US Navy Commander Reann Mommsen, a spokesperson for the US 7th Fleet affirmed that "The U.S. will fly, sail and operate wherever international law allows", adding that freedom of navigation operations "are not about any one country, nor are they about making political statements" (Browne \& Lendon, 2019). Commander Clay Doss, a U.S. 7th Fleet spokesman shared the view that "U.S. Forces operate in the Indo-Pacific region on a daily basis, including in the East Sea. All operations are designed in accordance with international law and demonstrate that the United States will fly, sail and operate wherever international law allows. That is true in the East Sea as in other places around the globe" (Werner, 2019). Also, both the U.S. Department of Defense and Department of State have helped build maritime capacity for Southeast Asian countries through the Indo Pacific Maritime Security Strategy in June 2019 and the Indo - Pacific Transparency Initiative in November 2019. Additionally, the Indo Pacific Strategy, including the East Sea policy, has been receiving strong bipartisan support. This was vigorously demonstrated by its "passage of the State and Foreign Operations, and Related Programs appropriations bill as a part of the end-of-year spending package, which contained $\$ 2.5$ billion to implement the Gardner-Markey Asia Reassurance Initiative Act (ARIA)" (U.S. Senate, 2019). Highlighting the passage, Senator Gardner believed that ARIA "will ensure the United States remains the pre-eminent Pacific power for generations to come", "will allow the U.S. government to speak with one voice to advance our nation's national security, economic interests, and values in the IndoPacific, a region critical to the success of our nation as the pre-eminent global superpower that respects human rights and the rule of law" (U.S. Senate, 2019). ARIA is to reaffirm both the Trump Administration and U.S. Congress's commitments to "freedom of navigation under the international law" and the "peaceful resolution of maritime and territorial disputes" (CRS, 2019). The 2019 National Defense Authorization Act (NDAA) perceived China as its strategic competitor while emphasizing China's intensive militarization and land reclamation in the East Sea.

At systematic/ international level, as a superpower, the US is strongly affected by regional and international factors in drafting its foreign policy. Any change in the balance of power in the disadvantageous vector for the U.S. or any nation-state' rise challenging the U.S. already set-world order will force the U.S. to recalculate its strategies to restore its power and influence. Also, as a superpower, the U.S. should express its responsibilities in paying respects for and legally abided by international law and ruled-based orders. The U.S.'s National Security Strategy (NSS 2017) and National Defense Strategy 2018 (NDS 2018) both labeled China (and Russia) as the U.S.'s leading strategic competitor in the region. In the Indo - Pacific, China's rise has been posing risks in various fields, including maritime security. Specifically, China's recent developments, including its unceasingly reclamations and militarization of artificial islands in the East Sea in order to legalize its "nine-dashed line" have been threatening regional rule-based order as well as the U.S.'s 
economic, military and strategic interests. Vice President Mike Pence at the $13^{\text {th }}$ EAS in November 2018 stated that "our commitment to uphold the freedom of the seas and skies, where we stand shoulder to shoulder with you for freedom of navigation" (U.S. Embassy in the Republic of Korea, 2018). It is added that "China's militarization and territorial expansion in the East Sea is illegal and dangerous, threatens the sovereignty of many nations and endangers the prosperity of the world" (U.S. Embassy in the Republic of Korea, 2018). Commander, US. Pacific Fleet, Admiral Scott H. Swift once emphasized that "China is challenging that principle (the principle of unfettered access to the shared global spaces for all nations) across all elements of national power characterized by the acronym DIME: Diplomatic, Information, Military and Economic" (U.S. Navy, 2017), adding that "freedom of navigation operations serve to reassert the inviolability of shared spaces and reaffirms America's commitment to upholding the rules-based international system" (U.S. Navy, 2017).

\section{US's policy implementation in the East Sea}

US's policy implementation in the East Sea can be seen mostly at national level and systematic levels under the leadership of President Trump.

At national level, with the slogan of "peace through strength", since the very beginning, the Trump Administration has focused on military build-up and rotation. In order to secure peace, stability and prosperity in the region, Chief of Naval Operations Admiral John Richardson put forth a vision in early 2017 for the U.S.'s Future Navy, in which "the nation needs a more powerful Navy, on the order of 350 ships, that includes a combination of manned and unmanned systems" (Maritime Issues, 2017). At the Shangri-La Dialogue, Secretary of Defense James Mattis declared in November 2017 that "currently $60 \%$ of all US Navy ships, 55\% of Army forces and about two-thirds of Fleet Marine forces are assigned to the US Pacific Command area of responsibility. Soon, 60\% of our overseas tactical-aviation assets will be assigned to this theatre." (Maritime Issues, 2017). In adaption to changing circumstances in the Indo - Pacific region, Secretary of Defense James Mattis officially "rename the US Pacific Command to US Indo - Pacific Command" in May 2018, which has about 375,000 civilian and military personnel, "more of the world than any of the five over geographic combatant commands and shares a border with each of its counterparts" (PACOM). Also, in August 2019, Secretary of Defense Mark Esper said that the U.S would invest in more bases in the region, "adding to its China containment activities in the region" (Jeong-ho \& $\mathrm{Ng}, 2019$ ). Admiral Philip S. Davidson, Commander of the U.S. Indo-Pacific Command in a hearing in February 2020 also revealed possibility of revisiting some of the places that the U.S. has operated and rotated forces. At systematic level, the U.S. continues to actively engage in key multilateral mechanism such as the ASEAN Regional Forum, the ASEAN Defense Ministers Meeting-Plus, and the East Asia Summit. Remarkably, the U.S. has utilized regional mechanisms to blame China's unlawful activities. Acting U.S. Defense Secretary Patrick Shanahan noted at the Shangri-La Dialogue in 2019 that the U.S. "will continue to support the freedom of navigation, free and open Indo - Pacific" while indirectly criticizing China for "toolkit of coercion" in the East Sea (CNN, 2019). Meanwhile, U.S. Envoy Robert O'Brien at the ASEAN - U.S. Summit in Thailand in 
November 2019 emphasized that China "has used intimidation to try to stop ASEAN nations from exploiting the off-shore resources, blocking access to 2.5 trillion dollars of oil and gas reserve alone" (Bankok Post, 2019). During the Munich Conference in February 2020, Secretary of Defense Mark Esper noted China's seizing and militarizing artificial islands in the East Sea which would "alter the landscape of power and reshape the world in their favor .....and often at the expense of others" (U.S. Department of Defense, 2020). Not only criticizing China's behavior, the U.S. showed support for exploiting legal measures in addressing territorial disputes in the East Sea, including early conclusion of Code of Conduct between China and ASEAN as well as its respect for the Tribunal ruling. On July 13, 2020, Secretary of State Mike Pompeo announced that China's expansive maritime claims in the East Sea were "completely unlawful". Though the U.S. has affirmed that it has not changed its neutrality policy on competing claims to legitimate land features in the East Sea, its new position has been already the strongest and most explicit support of the 2016 ruling. For the very first time, the U.S. has involved itself in the legal battle of diplomatic note exchanges between China and other claimants. Particularly, in June 2020, the U.S. Ambassador to the U.S. officially sent out a letter to the Secretary-General of the United Nation which reiterated its objections to China's maritime claims in the East Sea.While consolidating and deepening a network of allies and partners, the U.S. seeks to develop new partnerships with "pivotal players across the region, such as Indonesia, Malaysia, and Vietnam" to "address common challenges, to enhance shared capabilities, to increase defense investment where appropriate, to improve interoperability, to streamline information sharing, and to build networks of capable and like-minded partners" (U.S.
Department of Defense, 2018). In the relationship with its oldest ally in the region, the Philippines, joint military activities was planned to increase in 2019 from 262 to 281 (Heritage Foundation, 2019). Remarkably, the Trump Administration publicly declared its security protection of the Philippines for the very first time. During his visit to the Philippines in February 2019, Secretary of State Mike Pompeo affirmed that "As the East Sea is part of the Pacific, any armed attack on Philippine forces, aircraft or public vessels in the East Sea will trigger mutual defense obligations under Article 4 of our mutual defense treaty" (Cabato \& Mahtani, 2019). In the context that President Duterte planned to terminate the Visiting Forces Agreement, Admiral Philip S. Davidson, Commander of the U.S. Indo-Pacific Command expressed hope that the U.S. Department of State would be able to negotiate a solution that would secure the Visiting Forces Agreement while reaffirming that the 1951 Mutual Defense Treaty would be applied for excessive territorial claims in the East Sea. In the meantime, the Trump Administration has boosted its regional maritime capacity building efforts through the Indo - Pacific Maritime Security Initiative (U.S. Department of Defense, 2019) with increasing and extending funding till 2024 and the Indo - Pacific Transparency Initiative (U.S. Department of State, 2018). According to the Trump Administration, in the year of 2018, the US sold US\$ 9.42 billion worth of arms and provided more than US\$500 million in security assistance (more than double the previous year) to regional states. Moreover, for the first time ever, the U.S. conducted joint military exercises with ASEAN in September, 2019 to enhance capacities of ASEAN nations' naval forces in the fight against naval and disaster threats ( Harmer, 2019). To enhance 
U.S. presence in the region, ARIA is set to authorize \$1.5 billion annually for the period from 2019 to 2023, especially to address security concerns such as China's aggressive actions in the East Sea (CogitAsia, 2019).

The. U.S. has been straight-forward in communicating with China on the East Sea. After a high-level talk with Chinese counterpart in November 2018, Secretary of State Mike Pompeo highlighted the U.S. concerns about China's activities in the East Sea and "press China to live up its past commitments" of "non-confrontation" (CNBC, 2018) in the region. U.S. National Security Adviser John Bolton in 2019 strongly criticized China's actions in the East Sea as "completely unacceptable" and would "continue to pursue actions to prevent Beijing from turning the area into a new Chinese province" (ABC News, 2020). It is noteworthy to mention that the U.S. expressed its concern not only over China's illegal reclamation and militarization but also its interference with oil and gas activities in the East Sea, including Vietnam's long-standing exploration and production activities. In July 2019, Department Spokesperson Morgan Ortagus stated that "China's repeated provocative actions aimed at the offshore oil and gas development of other claimant states threaten regional energy security and undermine the free and open IndoPacific energy market" (U.S. Department of State, 2019). Then, the U.S. strongly believed that China should stop bullying its neighbors and refrain from provocative and destabilizing activities. Recently, upon China's sinking of a Vietnamese vessel in the vicinity of the Paracel islands in the East Sea, the U.S. has been among the first condemning China's asserting "unlawful maritime claims and disadvantage its Southeast Asian neighbors" in this water (U.S. Department of State, 2020). The U.S. Department of Defense highlighted that China's behavior "stands in contrast to the U.S.'s vision of a free and open Indo - Pacific region, in which all nations, large and small, are secure in their sovereignty, free from coercion, and able to pursue economic growth consistent with accepted international rules and norms" (U.S. Department of Defense, 2020). Instead of destabilizing the region, the U.S. called for focusing on taming the corona pandemic. Also, the Trump Administration has sought new ways to reduce risks of naval encounters in disputed waters, including the East Sea. Admiral John Richardson, Chief of US Naval Operations, at a meeting of the Atlantic Council in 2019, called for firmer rules governing encounters not only between navies but also coastguards and maritime militias, "so-called second and third sea forces that Beijing has used to advance its sovereignty claims" (Zhou, 2019). Previously in 2014, China and the U.S. agreed to the Code for Unplanned Encounters at Sea (CUES), a non-legally binding accord that was limited to reducing escalation of tensions and chances of clashes between naval vessels and military aircrafts only. So far, the two sides and other foreign Navies have not kicked off any new round of negotiation. Speaking with his counterpart in March 2020, Secretary of Defense Mark Esper expressed his concern over China's lasing U.S. Navy P-8A Poseidon maritime patrol aircraft west of Guam which violates the Code for Unplanned Encounters at Sea (CUES). Then, he raised the need for enhancing bilateral communication mechanisms to resolve escalation of crisis.

Throughout its history, the U.S. has conducted FONOPS, as recognized in the UNCLOS 1982, to stop coastal states with illegally excessive maritime claims from infringing its rights, freedom, and lawful uses of the sea and explorations of common goods in the sea. Formally established in 
1979, the FONOP is implemented by both the U.S. Department of State and Department of Defense in order to preserve the U.S. vital national interests in the seas. While the former leads diplomatic efforts to protest excessive maritime claims, the later carries out operational assertions against excessive maritime claims. The Trump Administration conducted the first FONOP very early, just four months after taking office. The first FONOP within twelve nautical miles around Scarborough Shoal since China seized it in 2012 was conducted in January 2018. U.S. Navy's sailing within 12 nautical miles of features claimed or occupied by China hit the highest record of nine times in 2019 since China started to conduct land reclamations in 2014. Previously, such FONOPs were carried five in 2018, six in 2017 under the Trump Administration. Also, the US. is no longer a single operator conducting FONOPs in the waterway. There have been other allies and partners joining with the U.S. Navy, namely warships of the Royal Australian Navy (RAN) in November 2019.

\section{Conclusion}

So far, there has not been any U.S. formal paper on the East Sea. However, the extent that President Trump and other senior officials have attached importance to the issue, at both individual and national level, in order to constrain and deter China's aggressiveness in the East Sea at regional level, has proved that the U.S. has indeed had a policy in this waterway. By applying three levels of analysis, it can be clearly seen how internal and external factors have had impact on the Trump's East Sea policy. On the one hand, the Trump Administration will continue to push "America's First" to serve for the upcoming Presidential Election, especially against the background of the novel corona pandemic's huge impacts on the country. On the other hand, though being a non-claimant in the East Sea and a non-UNCLOS member, the Trump Administration will maintain its decoupling with China in various areas, including the East Sea, in order to secure a "free and open Indo - Pacific". Hence, it is critical to closely observe US's move regarding the East Sea, then proactively and timely coordinating with other related countries, especially in the year Viet Nam undertaking ASEAN Chairmanship.

\section{Reference}

ABC news (2020), "Recent developments surrounding East Sea", https://abcnews.go.com/International/ wireStory/recent-developments-surrounding-southchina-sea-61602195, retrieved on March 2019.

Academia, Chapter three on Levels of Analysis and Foreign Policy, https://www.academia. edu/28941706/Chapter_Three_on_Levels_of_ Analysis_and_Foreign_Policy.

Bangkok Post (2019), "US Envoy decries Chinese intimidation in East Sea", https://www.bangkokpost. com/thailand/general/1786889/us-envoy-decrieschinese-intimidation-in-south-china-sea, retrieved on November 2019.

Ben Werner (2019), "Two U.S. Guided-Missile Destroyers Conduct FONOP Past Mischief Reef in East China Sea", USNI, https://news.usni.org/2019/02/11/41017, retrieved on 11 February 2019.

Business Insider (2019), "US flies B-52 bombers over East Sea for the $2^{\text {nd }}$ time in 10 days",https:// www.businessinsider.com/us-flies-b-52-bombersover-south-china-sea-for-the-2nd-time-in-10days-2019-3, retrieved on March 2019.

CFR (2019), "Sea power, US Navy and Foreign Policy”, https://www.cfr.org/backgrounder/sea-power-usnavy-and-foreign-policy, retrieved on August 2019.

CFR (2019), "US - China Strategic Competition in South and East China Seas: Background and Issues for Congress", https://fas.org/sgp/crs/row/R42784. pdf, retrieved on 26 November 2019. 
CFR (2006), "US Energy Dependence Undercutting U.S. National Security, Council Task Force Warns", https://www.cfr.org/news-releases/usenergy-dependence-undercutting-us-nationalsecurity-council-task-force-warns, retrieved on October 2006.

China Power CSIS, "How much trade transits the East Sea?",https://chinapower.csis.org/much-tradetransits-south-china-sea/

CNBC (2018), "US presses China to halt militarization of East Sea", https:/www.cnbc.com/2018/11/10/uspresses-china-to-halt-militarization-of-south-chinasea.html, retrieved on November 2018.

CNN (2019), "Singapore Shangrila defense conference", https://edition.cnn.com/2019/05/31/politics/ singapore-shangrila-defense-conference/index. html, retrieved on June 2019.

CogitAsia (2019), “The Asia Reassurance Initiative Act overlooking smaller players in Southeast Asia", https://www.cogitasia.com/the-asia-reassuranceinitiative-act-overlooking-smaller-players-insoutheast-asia/, retrieved on April 25, 2019.

CRS (2019), “ARIA”, https://fas.org/sgp/crs/row/ IF11148.pdf, retrieved on April 2019.

Heritage Foundation (2019), "Assessing the Global Operating Environment", https:/www.heritage.org/ military-strength/assessing-the-global-operatingenvironment/asia, retrieved on August 2019.

J. David Singer (1961), "The Level-of-Analysis Problem in International Relations", World Politics, Vol. 14, No. 1, pp. 77-92.

John Ikenberry (2014), “American Foreign Policy”, Oxford University, $7^{\text {th }}$ edition, page 3.

Joint Chief of Staff(2018), "National Military Strategy", https://www.jcs.mil/Portals/36/Documents/ Publications/UNCLASS_2018_National_Military_ Strategy Description.pdf, retrieved on June 2018.

Leonard Freegman (1971), Roger A. Riske, "Power and Politics in America", $5^{\text {th }}$ edition, p. 35.

Maritime Issues (2017), “The US naval build-up and Asia under the Trump Administration, http:// www.maritimeissues.com/us-new-administration/ the-us-naval-buildup-and-asia-under-the-trumpadministration.html, retrieved on July 2017.
Jerry Harmer (2019), "US promotes Free and Open IndoPacific at naval exercise", https://www.navytimes. com/news/your-navy/2019/09/02/us-promotes-freeand-open-indo-pacific-at-naval-exercise/, retrieved on September $2^{\text {nd }}, 2019$.

Oren Dorell (2018), "How China's military expansion threatens U.S. interests", USA Today, https:// www.usatoday.com/story/news/world/2018/05/18/ how-chinas-military-expansion-threatens-u-sinterests/621385002/, retrieved on May 2018.

PACOM, US PACOM Area of Responsibility, https:// www.pacom.mil/About-USINDOPACOM/ USPACOM-Area-of-Responsibility/

Regine Cabato,Shibani Mahtani (2019), "Pompeo promises intervention if Philippines is attacked in East Sea amid rising Chinese militarization", Washington Post, https://www. washingtonpost.com/world/pompeo-promisesintervention-if-philippines-is-attacked-in-southchina-sea-amid-rising-chinese-militarization/2019 /02/28/5288768a-3b53-11e9-b10b-f05a22e75865 story.html, retrieved on February 2019.

Rourke, J.T. \& Boyer M.A. (2010), “International politics on the world stage", McGraw Hill Higher Education, $8^{\text {th }}$ edition, Chapter 3.

Ryan Browne, Brad Lendon (2019), "US sails warship near contested islands in the East China Sea amid tension with China", CNN, https://edition.cnn. com/2019/08/28/politics/us-navy-south-china-sea/ index.html, retrieved on 29 August 2019.

Lee Jeong-ho, Teddy Ng, (2019), "New US military bases in Asia-Pacific 'likely to be temporary' for troop flexibility", https:/www.scmp.com/news/ china/diplomacy/article/3025125/new-us-militarybases-asia-pacific-likely-be-temporary-troop, retrieved on August 2019.

Laura Zhou (2019), "East Sea Trump military adviser calls firmer rules to stop near misses", https:/www. scmp.com/news/china/diplomacy/article/2185308/ south-china-sea-trump-military-adviser-callsfirmer-rules-stop, retrieved on February 2019.

Steven Stashwick (2019), "China's East Sea Militarization Has Peaked", Foreign Policy, https://foreignpolicy. com/2019/08/19/chinas-south-china-sea- 
militarization-has-peaked/, retrieved on August 2019.

The Atlantic (2018), "Read President Trump's U.S.

Naval Academy Commencement Address, https:// www.theatlantic.com/politics/archive/2018/05/readpresident-trumps-us-naval-academy-commencementaddress/561206/, retrieved on May 2018.

US State Department (2018), “Indo-Pacific Transparency Initiative", https://www.state.gov/indo-pacifictransparency-initiative/, retrieved on November $3^{\text {rd }}$ 2019.

US Department of State (2019), "Press Briefing”, https:// www.state.gov/briefings/department-press-briefingjuly-11-2019/, retrieved on July 2019.

U.S. Department of State (2019), "Press Statement", https://www.state.gov/chinese-coercion-on-oil-andgas-activity-in-the-south-china-sea/, retrieved on July 2019.

US Department of State (2020), "Press Statement", https:/www.state.gov/prcs-reported-sinking-of-avietnamese-fishing-vessel-in-the-south-china-sea/, retrieved on April 2020.

U.S. Department of Defense (2019), “China a rising threat to national security, says DOD leaders", https://www.defense.gov/Explore/News/Article/ Article/1784442/china-a-rising-threat-to-nationalsecurity-say-dod-leaders/, retrieved on March 2019.

US. Department of Defense (2020), "Immediate Release", https:/www.defense.gov/Newsroom/ Releases/Release/Article/2143925/china-coastguard-sinking-of-a-vietnam-fishing-vessel/, retrieved on April 2020.

US Department of Defense (2019), Indo - Pacific Strategy Report, https://media.defense.gov/2019/ Jul/01/2002152311/-1/-1/1/DEPARTMENTOF-DEFENSE-INDO-PACIFIC-STRATEGYREPORT-2019.PDF, retrieved on June $1^{\text {st }} 2019$.

U.S. Department of Defense (2018), "National Defense Strategy", https://dod.defense.gov/Portals/1/ Documents/pubs/2018-National-Defense-StrategySummary.pdf, retrieved on January 2018.

US. Department of Defense (2020), "Remarks by Secretary of Defense at the Munich Conference", https://www.defense.gov/Newsroom/Speeches/ Speech/Article/2085577/remarks-by-secretary- of-defense-mark-t-esper-at-the-munich-securityconference/, , retrieved on February 2020.

US Department of Defense (2018), "Remarks by Secretary Mattis at Plenary Session of the 2018 Shangri-La Dialogue", https:/www.defense.gov/Newsroom/ Transcripts/Transcript/Article/1538599/remarksby-secretary-mattis-at-plenary-session-of-the-2018shangri-la-dialogue/, retrieved on June $2^{\text {nd }} 2018$.

US Embassy in the Republic of Korea (2018), "Remarks by Vice President Pence at the $6^{\text {th }}$ US-ASEAN Summit”, https://kr.usembassy.gov/111418-remarks -by-vice-president-pence-at-the-6th-u-s-aseansummit/, retrieved on November 2018.

US Navy (2017), "Future of Asia", https://www.cpf. navy.mil/leaders/scott-swift/speeches/2017/09/ future-of-asia.pdf, retrieved on September 2017.

U.S. Senate (2019), "Press Release", https:/www. gardner.senate.gov/newsroom/press-releases/ gardner-markey-applaud-25b-in-governmentfunding-bill-to-implement-indo-pacific-policy, retrieved on December 2019.

White House (2018), "Prepared Remarks for Vice President Pence at the East Asia Summit Plenary Session", https:/www.whitehouse.gov/briefingsstatements/prepared-remarks-vice-president-penceeast-asia-summit-plenary-session/, retrieved on 15 November 2018

White House (2017), "National Security Strategy", https://www.whitehouse.gov/wp-content/ uploads/2017/12/NSS-Final-12-18-2017-0905-2. pdf, retrieved onDecember 2017.

White House (2017), "Remarks by President Trump at APEC CEO Summit in Da Nang, Viet Nam", https:/www.whitehouse.gov/briefings-statements/ remarks-president-trump-apec-ceo-summit-danang-vietnam/, retrieved on November 2017.

White House (2019), "Remarks by Vice President Pence", https://www.whitehouse.gov/briefingsstatements/remarks-vice-president-pence-fredericv-malek-memorial-lecture/, retrieved on October 2019. 


\title{
CÁC CẤP ĐỘ PHÂN TÍCH TỬ LÝ THUYẾT ĐẾN THỰC TIỄN - TRƯỜNG HỢP NGHIÊN CÚU ĐIỂN HÌNH: CHIINH SÁCH BIỂN ĐÔNG CỦA MỸ DƯỚI CHÍNH QUYỀN TRUMP
}

\author{
Phạm Minh Thu \\ Học viện Ngoại giao Việt Nam, Vu Châu Mỹ, Bộ Ngoại giao \\ 69 Chùa Láng, Đống Đa, Hà Nội, Việt Nam
}

Tóm tắt: Ba cấp độ phân tích (cá nhân, quốc gia và hệ thống quốc tế) được công nhận rộng rãi trong phân tích chính sách đối ngoại có thể được vận dụng để lý giải liệu Chính quyền Trump có thực sự có chính sách Biển Đông hay không. Ở cấp độ cá nhân, Tổng thống Trump lần đầu tiên công bố "Chiến lược Ấn Độ - Thái Bình Dương tự do và mở" của Mỹ vào tháng 11/2017, theo đó Biển Đông được coi là nhân tố quan trọng của trụ cột an ninh nhằm duy trì vùng trời và không gian hàng hải tự do và mở ở khu vực. Ở cấp độ quốc gia, Biển Đông tiếp tục được nhắc lại trong các Chiến lược quốc gia của Mỹ gồm Chiến lược An ninh Quốc gia, Chiến lược Quốc phòng Quốc gia và Chiến lược Quân sự Quốc gia. Bên cạnh đó, các thành viên trong nội các Mỹ và các nghị sĩ Quốc hội Mỹ cũng thể hiện sự ủng hộ đối với Chiến lược Ấn Độ - Thái Bình Dương nói chung và chính sách Biển Đông của Mỹ nói riêng. Để đương đầu với sự hung hăng trên biển của Trung Quốc ở cấp độ hệ thống, Chính quyền Trump đã không ngừng triển khai sức mạnh đáng kể, bao gồm việc tăng cường hiện diện quân sự, hỗ trợ xây dựng năng lực hàng hải cho khu vực cũng như triển khai các hoạt động tự do hàng hải (FONOP) thường xuyên. Trong bối cảnh tranh chấp lãnh thổ tại Biển Đông tiếp tục diễn biến phức tạp và khó lường, việc đánh giá kỹ lưỡng chính sách Biển Đông của Chính quyền Trump sẽ có ý nghĩa đối với các nước có yêu sách ở vùng biển này, trong đó có Việt Nam.

Tù khóa: Các cấp độ phân tích, Trump, chính sách, Biển Đông. 